\title{
Gastrointestinal parasites in stray and shelter cats in the municipality of Rio de Janeiro, Brazil
}

\author{
Parasitos gastrintestinais de gatos de rua e de abrigo da cidade do Rio de Janeiro, Brasil \\ Pâmela Figueiredo Pereira ${ }^{1}$; Alynne da Silva Barbosa ${ }^{1,2}$; Ana Paula Pereira de Moura ${ }^{1}$; Marcelo Leitão Vasconcellos ${ }^{1}$; \\ Claudia Maria Antunes Uchôa²; Otílio Machado Pereira Bastos²; Maria Regina Reis Amendoeira ${ }^{1 *}$ \\ ${ }^{1}$ Laboratório de Toxoplasmose e outras Protozooses, Instituto Oswaldo Cruz, Fundaçáo Oswaldo Cruz - FIOCRUZ, Rio de Janeiro, \\ RJ, Brasil \\ ${ }^{2}$ Departamento de Microbiologia e Parasitologia, Instituto Biomédico, Universidade Federal Fluminense - UFF, Niterói, RJ, Brasil
}

Received January 17, 2017

Accepted March 24, 2017

\begin{abstract}
The increasingly urban nature of the population has led many people to choose independent pets, such as cats. This situation has also made it possible for these animals to be abandoned, thus increasing the numbers of cats on the streets and in shelters. These animals can act as a source of infection for other hosts. Between 2014 and 2015, the frequency of gastrointestinal parasites in captive and stray cats in the municipality of Rio de Janeiro was analyzed. Ninety-one fecal samples were collected from captive cats and 172 from stray cats. Centrifugal sedimentation and flotation techniques were used. The frequency of parasites among the stray cats was $77.3 \%$, and this was significantly higher than the frequency observed in captive cats (49.5\%). Helminths were detected more frequently, and hookworms were the parasites most detected. Toxocara cati, Cystoisospora sp. and Dipylidium caninum were also detected. No statistical difference in the frequency of parasites was observed between the sexes among the captive cats. However, among the stray cats, males $(85.5 \%)$ presented higher positivity than females $(71.8 \%)$. The high frequency of hookworms, which are the agent for "cutaneous larva migrans" in humans, shows the need to control parasitic infections among the cats studied.
\end{abstract}

Keywords: Cats, feral cat, zoonosis, hookworms, epidemiology.

\section{Resumo}

O aumento da população urbana contribuiu para que muitas pessoas escolhessem um animal de estimaçáo independente, como o gato. Esta situação possibilita o abandono desses animais, aumentando o número de gatos nas ruas e nos abrigos. Esses animais, entáo, podem servir como fonte de infecçấo para outros hospedeiros. Entre 2014 a 2015 foi analisada a frequência de parasitos gastrintestinais em gatos cativos e de rua na cidade do Rio de Janeiro. Foram coletadas 91 amostras fecais de gatos cativos e 172 de gatos de rua, sendo essas processadas pelas técnicas de centrífugo sedimentação e flutuação. A frequência de parasitos nos gatos de rua foi $77,3 \%$, sendo esta significativamente maior do que a evidenciada nos cativos, $49,5 \%$. Os helmintos foram mais detectados, sendo ancilostomídeos os parasitos mais evidenciados. Também foram detectados, Toxocara cati, Cystoisospora sp. e Dipylidium caninum. Não foi observada diferença estatística na frequência de parasitos entre o sexo nos gatos cativos, porém nos de rua, os machos $(85,5 \%)$ apresentaram positividade maior do que as fêmeas $(71,8 \%)$. A elevada frequência de ancilostomídeos, agente da "Larva Migrans Cutânea" no homem, demonstra a necessidade de controle das infecçôes parasitárias nos gatos estudados.

Palavras-chave: Gatos, gato feral, zoonose, ancilostomídeos, epidemiologia.

There are many etiological agents that can infect cats and give rise to diseases, and gastrointestinal parasites are prominent among them. These parasites are very common among these animals, both in rural and in urban areas, worldwide. These parasitoses may give

\footnotetext{
*Corresponding author: Maria Regina Reis Amendoeira. Laboratório de Toxoplasmose e outras Protozooses, Instituto Oswaldo Cruz, Fundaçáo Oswaldo Cruz - FIOCRUZ, Avenida Brasil, 4365, Manguinhos, CEP 21045-900, Rio de Janeiro, RJ, Brasil. e-mail: amendoeira.fiocruz@gmail.com; amendoei@ioc.fiocruz.br
}

rise to different clinical manifestations, depending mainly on the parasite species, parasite load and host immunity (BARUTZKI \& SCHAPER, 2003). Gastrointestinal parasites in cats are of great importance, not only because of their spoliative action towards the host, but also because of the possibility that some species might infect humans. Some parasitic zoonoses are associated with contact between humans and companion animals, especially cats and dogs (RAGOZO et al., 2002). Prominent among these are Ancylostoma sp. and Toxocara sp., which cause significant pathogenic 
alterations in humans that are known as "cutaneous larva migrans" and "visceral larva migrans", respectively (RAGOZO et al., 2002; BOWMAN et al., 2010; LEE et al., 2010).

A variety of factors influence the frequency of parasitoses in cats. These include the geographical region, frequency of veterinary medical care, level of care that owners provide, habits of the animal population, season of the year and type of cat population. In addition to these factors, those relating to the age, sex and even the breed of the cat can also be included (LABARTHE et al., 2004; HAJIPOUR et al., 2016).

So far, few studies have yet assessed or, compared gastrointestinal parasitoses between stray and shelter cat populations. The study by Labarthe et al. (2004), which compared the frequencies of occurrence of parasites between stray cats $(77.7 \%)$ and shelter cats $(22.3 \%)$ in Rio de Janeiro, Brazil, is the only such study in the literature. The frequency of gastrointestinal parasites among stray cats in Iran has ranged from $94 \%$ to $97.3 \%$ and in Spain from $89.7 \%$ to $100 \%$ (CALVETE et al., 1998; MILLÁN \& CASANOVA, 2009; MOHSEN \& HOSSEIN, 2009; HAJIPOUR et al., 2016). Among shelter cats in Australia, the frequency reported was 30.3\%, while in Brazil it ranged from 67.12\% to 100\% (PALMER et al., 2008; COELHO et al., 2009; RAMOS et al., 2013). Considering the importance of gastrointestinal parasitoses to cats' health and public health and the lack of information on this topic regarding domestic cats in Brazil, the present study had the aim of comparing the frequencies of gastrointestinal parasitoses among captive domestic cats living in shelters and among stray cats, in the city of Rio de Janeiro. The presence of parasites was correlated with the type of management used and the animals' sex.

This study received prior approval from the Animal Ethics Committee (CEUA) of FIOCRUZ, under license number LW 53/13 (P 24/13.7). Between August 2014 and October 2015, fecal samples from two different cat populations in the city of Rio de Janeiro were analyzed: one of cats living in a municipal shelter and the other of cats that were living freely in an urban space in the city. The municipal shelter was located in the Guaratiba district and had an extensive open-air area comprising grassy and bare-earth portions that allowed circulation of the confined animals. The population density in the shelter was 0.07 cats $/ \mathrm{m}^{2}$. This area was subdivided using aluminum fences reinforced with masonry corners, with concrete pipes and wooden huts. In addition, the entire space was delimited by high fences with aluminum sheeting in the upper portion to ensure that the animals would be unable to escape. The stray cats that were included in this study were mainly living in the area surrounding a condominium of apartments for residents of high purchasing power, in the Barra da Tijuca district, which also belongs to the city of Rio de Janeiro. The condominium is geographically located at latitude $22.988030 \mathrm{~S}$ and longitude 43.355084 W. This location is surrounded by restored sandspit and mangrove swamp vegetation, with flora and fauna typical of the Atlantic Forest region. This district comprises a flat urban area alongside the only preserved mangrove swamp area within the city's urban space. In this condominium, the estimated cat population density is 0.0002 cats $/ \mathrm{m}^{2}$. It contains several areas that have been prepared for stray cats, which are known locally as "cat islands". These "islands" have rudimentary enclosures made of plastic or wood, constructed on platforms, with food and water bowls inside them. The structures are located at strategic points of the condominium so that they are camouflaged, in areas of bare earth, grass and trees.

Fecal samples were collected from the cats according to convenience, one-by-one. Samples were obtained from a total of 263 animals, of which 91 were captive shelter cats $(56$ females and 35 males). From the condominium, samples were obtained from a total of 172 cats (103 females and 69 males).

The captive cats at the municipal shelter were a population mostly consisting of castrated animals without a defined breed that had been rescued from the streets or had been abandoned. At this shelter, the cats were fed with manufactured cat food and received drinking water, and they were managed by handlers daily. All the animals received an annual anti-rabies vaccine from a veterinary medical service and sporadically received anthelmintic drugs. The shelter does not have litter boxes and therefore the cats used the environment of this cattery to defecate. Their feces were then randomly collected. The stray cat population that inhabited the condominium also received manufactured cat food and water that was supplied by a handler hired by the condominium. These animals also used the environment for defecation, because no litter boxes were provided for them. Most of these cats did not belong to any defined breed and only a few had been castrated. These animals had not received anti-rabies vaccine, or any anthelmintic drugs. Because these cats were living freely in an environment of sandspits and natural vegetation, with little contact with humans, many of them had ended up acquiring feral behavior.

The cats were caught with the aid of specific net. For the stray cat population, an artisanal cage trap was also used, which was adapted to the doors of the "cat island" shelters. After these cats had been caught, they were housed individually in specific transportation boxes and were then taken to the sample collection area. The entire animal containment stage was conducted manually by the handlers at each location. After fecal material, had been collected, the cats were taken back to where they had been caught.

Feces were collected by means of intestinal lavage using physiological solution, with the aid of a sterile urethral probe that had previously been lubricated with mineral oil. The product from the fecal lavage was transferred to $15 \mathrm{~mL}$ tubes with a conical base. The samples thus collected were then transported in insulated boxes containing recyclable ice, to the Parasitology Laboratory of the Biomedical Institute, Fluminense Federal University. In the laboratory, the sample were processed by means of parasitological centrifugation techniques: sedimentation in conical tubes, using an adaptation of the technique described by Ribeiro \& Furst (2012); and floatation in sucrose solution, as described by Sheather (1923) and modified by Huber et al. (2003). The slides obtained through each technique were read and photomicrographs were produced using a binocular optical microscope (Olympus ${ }^{\circledR}$ BX 41), at a magnification of $100 \mathrm{X}$. The findings were confirmed at $400 \mathrm{X}$ if necessary. The microscope was coupled to a digital camera (Samsung ${ }^{\circledR}$ SDC415) and the image capture software used was Honestech $^{\circledR}$ TVR. For the identification of the parasites, their evolutive forms were measured with an ocular micrometer coupled to the microscope in an increase of $400 \mathrm{X}$. After the measurement, the morphometric data were compared with scientific literature (TAYLOR et al., 2010). 
Fisher's exact test was used to statistically evaluate the frequencies of evolutive forms of the gastrointestinal parasites that were diagnosed in the cat populations and also to compare the frequency of parasitoses between the sexes. All the analyses were performed using the GraphPad Prism software, version 7, with a 5\% confidence interval and $95 \%$ precision.

The frequencies of gastrointestinal parasites were $49.5 \%$ (45/91) among the captive shelter cats and $77.3 \%$ (133/172) among the stray cats. Helminths occurred more frequently than protozoa, in both groups of cats. The stray cats presented statistically significant higher frequencies than the captive shelter cats, regarding positive findings of both protozoa and helminths (Table 1).

Among the 91 samples from captive shelter cats that were analyzed, hookworm eggs were the evolutive form most often detected, followed by egg capsules of Dipylidium caninum, oocysts of Cystoisospora felis and eggs of Toxocara cati. Among the 172 samples collected from stray cats, the evolutive forms most often diagnosed were hookworm eggs, followed by oocysts of C. felis and Cystoisospora rivolta, eggs of T. cati and egg capsules of D. caninum. The positivity for hookworms and for protozoa of the genus Cystoisospora presented statistical differences in comparisons between the two groups of cats studied (Table 2).

From analysis on the frequencies of gastrointestinal parasites according to the animals' sex, it was observed that overall, the males presented higher positivity for parasitoses. However, for the captive shelter cats, there was no statistically significant difference in the frequency of parasitoses according to sex. Among both the captive cats and the stray cats, independent of sex, hookworms were the parasites most often detected (Table 3).

Both the captive cats and the stray cats presented higher frequency of monoparasitism, i.e. $46.2 \%(42 / 91)$ and $58.1 \%$ (100/172), than of polyparasitism, i.e. 3.3\% (3/91) and $19.2 \%$ (33/172), respectively. Polyparasitism was diagnosed more frequently in the fecal samples from the stray cats, in 33 of them. In these cases, the parasite association most often detected consisted of the hookworms, C. felis and C. rivolta (Table 4).

Evolutive forms of helminths and protozoa were detected in fecal material both from the captive cats in a municipal shelter and from the stray cats that circulated freely in a condominium located in the city of Rio de Janeiro. This study differed from most others, which had generally analyzed fecal samples from a single population group of cats. In this study, $49.5 \%$ of the fecal material from the captive shelter cats was found to be positive for gastrointestinal parasites. This proportion was lower than what was detected among captive cats at zoonosis control centers (CCZs) in other states in Brazil, such as in Andradina, São Paulo (COELHO et al., 2009), and in Cuiabá, Mato Grosso (RAMOS et al., 2013), where $100 \%$ and $67.1 \%$ were positive, respectively. In Australia, Palmer et al. (2008) compared the frequencies of gastrointestinal parasitoses between populations of cats living in their owners' homes and in captivity in shelters. Their rate of positive findings among shelter cats was lower than what was detected in Rio de Janeiro (30.3\%). The lower frequency reported in the present study than in others in Brazil was possibly

Table 1. Frequencies of helminths and protozoa detected in fecal material from captive cats in a municipal shelter and stray cats in a condominium in Rio de Janeiro, RJ.

\begin{tabular}{lccr}
\hline \multicolumn{1}{c}{ Parasites } & Shelter cats $(\mathbf{n}=\mathbf{9 1})$ & Stray cats $(\mathbf{n}=\mathbf{1 7 2})$ & p-value \\
\hline Helminths & $44(48.4 \%)$ & $118(68.6 \%)$ & 0.0057 \\
Protozoa & $2(2.2 \%)$ & $39(22.7 \%)$ & $<0.0001$ \\
Total number of positive samples & $45(49.5 \%)$ & $133(77.3 \%)$ & $<0.0001$ \\
\hline
\end{tabular}

Table 2. Frequencies of evolutive forms of gastrointestinal parasites detected in fecal material from captive cats in a municipal shelter and stray cats in a condominium in Rio de Janeiro, RJ.

\begin{tabular}{lccc}
\hline \multicolumn{1}{c}{ Parasites } & Positive captive cats $(\mathbf{n}=\mathbf{4 5})$ & Positive stray cats $(\mathbf{n}=\mathbf{1 3 3})$ & p-value \\
\hline Hookworms & $42(93.3 \%)$ & $117(87.9 \%)$ & 0.0009 \\
Toxocara cati & $1(2.2 \%)$ & $3(2.2 \%)$ & $>0.9999$ \\
Cystoisospora felis & $2(4.4 \%)$ & $33(24.8 \%)$ & $<0.0001$ \\
Cystoisospora rivolta & $0(0.0 \%)$ & $22(16.5 \%)$ & $<0.0001$ \\
Dipylidium caninum & $3(6.7 \%)$ & $3(2.2 \%)$ & 0.4197 \\
\hline
\end{tabular}

Table 3. Frequencies of gastrointestinal parasites according to sex among captive cats at a municipal shelter and stray cats in a condominium in Rio de Janeiro, RJ.

\begin{tabular}{|c|c|c|c|c|c|c|}
\hline \multirow{2}{*}{ Parasites } & \multicolumn{3}{|c|}{ Shelter cats } & \multicolumn{3}{|c|}{ Stray cats } \\
\hline & Male $(n=35)$ & Female $(n=56)$ & p-value & Male $(n=69)$ & Female $(n=103)$ & p-value \\
\hline Hookworms & $17(48.6 \%)$ & $25(44.6 \%)$ & 0.8294 & $52(75.4 \%)$ & $65(63.1 \%)$ & 0.0984 \\
\hline Toxocara cati & 0 & $1(1.8 \%)$ & $>0.9999$ & $2(2.9 \%)$ & $1(0.9 \%)$ & 0.5651 \\
\hline Cystoisospora felis & 0 & $2(3.6 \%)$ & 0.5214 & $15(21.7 \%)$ & $18(17.4 \%)$ & 0.5549 \\
\hline Cystoisospora rivolta & 0 & 0 & $>0.9999$ & $10(14.5 \%)$ & $12(11.6 \%)$ & 0.6444 \\
\hline Dipylidium caninum & $2(5.7 \%)$ & $1(1.8 \%)$ & 0.5563 & $1(1.6 \%)$ & $2(1.9 \%)$ & $>0.9999$ \\
\hline Total & $18(51.4 \%)$ & $27(48.2 \%)$ & 0.831 & $59(85.5 \%)$ & $74(71.8 \%)$ & 0.0416 \\
\hline
\end{tabular}


Table 4. Parasite associations detected in the fecal samples from captive cats in a municipal shelter and stray cats in a condominium in Rio de Janeiro, RJ.

\begin{tabular}{lcc}
\hline \multicolumn{1}{c}{ Parasite association } & Shelter cats & Stray cats \\
\hline Hookworms + Cystoisospora felis & $1(33.3 \%)$ & $8(24.2 \%)$ \\
Hookworms + Cystoisospora rivolta & 0 & $4(12.1 \%)$ \\
Hookworms + Dipylidium caninum & $1(33.3 \%)$ & $1(3 \%)$ \\
Hookworms + Toxocara cati & $1(33.3 \%)$ & $1(3 \%)$ \\
Cystoisospora felis + Cystoisospora rivolta & 0 & $7(21.2 \%)$ \\
Hookworms + Cystoisospora felis + Dipylidium caninum & 0 & $1(3 \%)$ \\
Hookworms + Cystoisospora felis + Toxocara cati & 0 & $1(3 \%)$ \\
Hookworms + Cystoisospora felis + Cystoisospora rivolta & 0 & $9(27.3 \%)$ \\
Hookworms + Cystoisospora rivolta + Toxocara cati & 0 & $1(3 \%)$ \\
Total number with polyparasitism & $3(100 \%)$ & $33(100 \%)$ \\
\hline
\end{tabular}

due to the necropsy techniques used in the studies in São Paulo and Mato Grosso, which showed infections that cannot easily be diagnosed by means of parasitological techniques involving fecal concentration.

The gastrointestinal parasitoses shown in the fecal samples from the captive animals may have occurred because of a variety of factors. Among these, the following can be highlighted: environmental contamination with feces from parasitized cats; concentration of animals, which favors direct contact between individuals and their excreta; presence of bare earth, which favors cats' habit of burying their feces and also makes it difficult to clean the environment; and consumption of water from shallow vessels, which tend to more easily become contaminated. Ferreira et al. (2011) emphasized that one of the problems of shelters is the high concentration of animals is a small geographical space. Ultimately, this ends up contributing towards reinfection among the animals, caused by different etiological agents. It is important to highlight that the animals at this municipal shelter in Rio de Janeiro only received drugs sporadically, which may have favored infection.

The frequency of parasite structures in the fecal material from the stray cats in the condominium was $77.3 \%$. Frequencies much higher that this were reported among stray cats in Iran, of $97.3 \%$ and $94 \%$, respectively by Mohsen \& Hossein (2009) and Hajipour et al. (2016). In Spain, high positivity for gastrointestinal parasites among free-living cats was also shown by Calvete et al. (1998) (89.7\%) and by Millán \& Casanova (2009), (100\%). It should be noted that in all these studies, the stray cats were necropsied. This procedure has been undertaken in studies involving stray cats that, because they have been free in their environment for a long time, have acquired feral habits and are therefore difficult to restrain. There were feral cats among the free-living animals of the present study, and these were subjected only to physical containment by an experienced handler, thus minimizing the animals' stress as much as possible.

The higher frequency of parasitoses in the stray cat population than in the shelter cat population in the present study was concordant with the results reported by Labarthe et al. (2004), who analyzed gastrointestinal parasitoses in different groups of cats in Rio de Janeiro, by means of necropsies. Moreover, other parasites, which don't were detected in this study, i.e.: Toxascaris leonina and Physaloptera praeputialis were found by Labarthe et al.
(2004). The high frequencies generally reported among stray cats, as observed among the cats in the condominium, may be due mainly to the fact that these animals are free-living and therefore are able to roam between different localities. It should be noted that this condominium has an extensive natural environment with sandspit and mangrove swamp vegetation. It is therefore an environment that favors maintenance of the biological cycle of some parasite species. It is important to highlight that although these cats received some daily care, they did not receive anthelmintic drugs.

Evolutive forms of helminths, especially nematodes, were detected more frequently in the fecal samples from cats in both groups. Hookworm eggs were the evolutive forms most observed in the fecal samples and their frequency was higher among the captive cats than among the stray cats. Results from captive cats that were similar to those of the present study were reported among cats at a CCZ in Andradina, São Paulo (96.07\%), by Coelho et al. (2009). High frequency of Ancylostoma sp. (78\%), but less than that of the present study, was reported by Anderson et al. (2003) among feral cats in Florida. High prevalence of hookworms may be associated with the direct monoxenous life cycle of nematodes, high egg production by females and a capacity among filarial larvae to promote active infection. Furthermore, these infective larvae develop better in tropical areas with sandy soils, humid environments and temperatures between 25 and $30^{\circ} \mathrm{C}$ (BOWMAN et al., 2002). These environmental conditions were observed in both localities studied here, in which cats circulated in areas of bare earth that was typically sandy.

The low frequency of eggs of Toxocara cati that was observed in this study, differed from what had been seen in other studies. In the cities of São Paulo and Guarulhos, Ragozo et al. (2002) showed that the frequency of occurrence of $T$. cati among cats in municipal shelters was $31.16 \%$, i.e. much higher than among the captive cats in the present study. The same frequency was reported among the stray cats in the condominium. This was also lower that what was reported by Calvete et al. (1998) in the middle Ebro valley, in Spain, where stray cats presented positivity for T. cati of $55.2 \%$. Although the ages of the captive and stray cats included in the present study were not ascertained, their large physical size suggested that most of them were at least six months of age. This variable may have caused the low frequency of this nematode. According to Soulsby (1982), the frequency of 
somatic migration of parasites increases as these animals develop towards adulthood. Through this, ascarid larvae tend to become encysted in tissues, thus diminishing the rate of evolution towards adult parasites in the small intestine, which ends up determining lower egg production.

Protozoa were detected mainly in the fecal samples from the stray cats. The only genus detected, in the material both from the stray cats and from the captive cats, was Cystoisospora. Through the morphology of the oocysts and also through measuring them under an optical microscope using a ocular micrometric, it was possible to differentiate the species of this genus, into $C$. felis and C. rivolta. In the fecal samples from the captive cats, it was only possible to detect the species $C$. felis, as also observed in $10.2 \%$ of the fecal samples from shelter cats in Australia (PALMER et al., 2008), whereas the fecal material from the stray cats was positive for both $C$. felis and C. rivolta.

Because the stray cats were in an extensive sandspit environment that had a rich and diversified fauna of birds and rodents, they may have returned to hunting. In this manner, they may have ingested monozoic cysts of the coccidians that are present in the musculature of their prey, which would thus have contributed towards increasing the frequency of the parasitoses. When cats are parasitized by Cystoisospora sp., they tend to present asymptomatic infections. $C$. felis and $C$. rivolta are unimportant from a public health point of view, although some authors have emphasized that when cats that were previously infected with Toxoplasma gondii become infected with $C$. felis for the first time, they may go back to eliminating oocysts of T. gondii (LINDSAY et al., 1997).

Egg capsules of Dipylidium caninum were little diagnosed in the fecal material of either cat population. High frequencies of this cestode have been reported in studies that investigated gastrointestinal parasites by means of necropsies with in stray cats in the Iran and in the Brazil among captive cats at a CCZ in Andradina, SP and among stray cats in Rio de Janeiro, RJ (MOHSEN \& HOSSEIN, 2009; COELHO et al., 2009; LABARTHE et al., 2004). When coproparasitological techniques alone are used for investigating $D$. caninum, its frequency of occurrence generally tends to be underestimated because the egg capsules are not always detected in the feces (GENNARI et al., 1999). This may also have occurred in the present study. Presence of this cestode was expected, given that at the time of collecting the samples, it was observed that some of the animals were infested with fleas, which are intermediate hosts of these parasites.

In the present study, there was no variation in the frequency of parasites between the sexes among the captive cats. In other studies on different populations of cats, such as cats living in their owners' homes in Italy, stray cats in Iran and captive cats at a CCZ in Cuiabá, Mato Grosso, Brazil, sex was also not a variable that influenced the prevalence rates of the gastrointestinal parasites that were detected (RIGGIO et al., 2013; HAJIPOUR et al., 2016; MOHSEN \& HOSSEIN, 2009; RAMOS et al., 2013). Among the captive shelter cats of the present study, sex did not have any influence on infection. However, in the population of stray cats, the males presented higher frequency of parasitoses than the females. According to Smith et al. (1992), male adult cats explore larger geographical areas than do females, which favors both infection and dispersion of parasite structures. The stray cats of the condominium presented this behavior, even though each individual belonged to one "cat island". They roamed between the "cat islands" (especially the uncastrated males) and sometimes had territorial disputes.

Monoparasitism was the pattern that was most observed in the samples that were positive for gastrointestinal parasites. This was also the pattern reported in other studies on fecal material from domestic cats (GENNARI et al., 1999; RAGOZO et al., 2002; LORENZINI et al., 2007; STALLIVIERE et al., 2009; FERREIRA et al., 2011; RIGGIO et al., 2013). It is important to emphasize that the high frequency of monoparasitism consisted of a parasite profile in which hookworm eggs were the evolutive form most often detected in both cat populations studied here.

The marked presence of parasites, especially hookworms, that was shown in this study, emphasizes the importance of controlling parasite infections in cats in Rio de Janeiro. In the populations studied here, sanitary management needs to be prioritized, with emphasis on routine use of anthelmintic drugs, with the aim of at least controlling the helminth parasite fauna. The sanitary measures will not only benefit the cats' health but also have great importance for public health, given that they will prevent transmission of zoonotic parasites such as hookworms, T. cati and D. caninum, which were shown in this study. Another highly relevant sanitary measure would be to make owners aware of the importance of having their cats castrated, which would minimize the stimulus for these cats to roam around in external environments, thereby preventing their exposure to parasitic infections.

\section{Acknowledgements}

We would like to thank the Department of Animal Promotion and Defense of the municipality of Rio de Janeiro and ASSAPE association. We are grateful to Mauro Lúcio de Andrade and all those who participated in the sampling.

\section{References}

Anderson TC, Foster GW, Forrester DJ. Hookworms of feral cats in Florida. Vet Parasitol 2003; 115(1): 19-24. PMid:12860064. http:// dx.doi.org/10.1016/S0304-4017(03)00162-6.

Barutzki D, Schaper R. Endoparasites in dogs and cats in Germany 1999-2002. Parasitol Res 2003;90(Suppl 3): 148-150. PMid:12928886. http://dx.doi.org/10.1007/s00436-003-0922-6.

Bowman DD, Hendrix CM, Lindsay DS, Barr SC. Feline clinical parasitology. Iowa: Iowa State University Press; 2002. http://dx.doi. org/10.1002/9780470376805.

Bowman DD, Montgomery SP, Zajac AM, Eberhard ML, Kazacos KR. Hookworms of dogs and cats as agents of cutaneous larva migrans. Trends Parasitol 2010; 26(4): 162-167. PMid:20189454. http://dx.doi. org/10.1016/j.pt.2010.01.005.

Calvete C, Lucientes J, Castillo JA, Estrada R, Gracia MJ, Peribáñez MA, et al. Gastrointestinal helminth parasites in stray cats from the midEbro Valley, Spain. Vet Parasitol 1998; 75(2-3): 235-240. PMid:9637225. http://dx.doi.org/10.1016/S0304-4017(97)00182-9. 
Coelho WMD, Amarante AFT, Soutello RVG, Meireles MV, Bresciani KDS. Occurrence of gastrointestinal parasites in fecal samples of cats in Andradina city, São Paulo. Rev Bras Parasitol Vet 2009; 18(2): 46-49. PMid:19602317. http://dx.doi.org/10.4322/rbpv.01802010.

Ferreira FS, Pereira-Baltazar P, Parreira R, Padre L, Vilhena M, Tavira LT, et al. Intestinal parasites in dogs and cats from the district of Évora, Portugal. Vet Parasitol 2011; 179(1-3): 242-245. PMid:21377803. http:// dx.doi.org/10.1016/j.vetpar.2011.02.003.

Gennari SM, Kasai N, Pena HFJ, Cortez A. Occurrence of protozoa and helminths in faecal samples of dogs and cats from São Paulo city. Braz J Vet Res Anim Sci 1999; 36(2): 87-91.

Hajipour N, Baran AI, Yakhchali M, Khojasteh SMB, Hesari FS, Esmaeilnejad B, et al. A survey study on gastrointestinal parasites of stray cats in Azarshahr, (East Azerbaijan province, Iran). J Parasit Dis 2016; 40(4): 1255-1260. PMid:27876926. http://dx.doi.org/10.1007/ s12639-015-0663-3.

Huber F, Bomfim TC, Gomes RS. Comparison between the efficiency of the formaldehyde-ether sedimentation technique and the sugar fluctuation technique for the detection of Giardia sp. cysts and Cryptosporidium sp. oocysts in fecal samples from calves. Rev Bras Parasitol Vet 2003; 12: 135-137.

Labarthe N, Serrão ML, Ferreira AMR, Almeida NKO, Guerrero J. A survey of gastrointestinal helminths in cats of the metropolitan region of Rio de Janeiro, Brazil. Vet Parasitol 2004; 123(1-2): 133-139. PMid:15265577. http://dx.doi.org/10.1016/j.vetpar.2004.06.002.

Lee ACY, Schantz PM, Kazacos KR, Montgomery SP, Bowman DD. Epidemiologic and zoonotic aspects of ascarid infections in dogs and cats. Trends Parasitol 2010; 26(4): 155-161. PMid:20172762. http:// dx.doi.org/10.1016/j.pt.2010.01.002.

Lindsay DS, Dubey JP, Blagburn BL. Biology of Isospora spp. from humans, nonhuman primates, and domestic animals. Clin Microbiol Rev 1997; 10(1): 19-34. PMid:8993857.

Lorenzini G, Tasca T, Carli GA. Prevalence of intestinal parasites in dogs and cats under veterinary care in Porto Alegre, Rio Grande do Sul, Brazil. Anim Sci 2007; 44(2): 137-145. http://dx.doi.org/10.11606/issn.16784456.bjvras.2007.26652.

Millán J, Casanova JC. High prevalence of helminth parasites in feral cats in Majorca Island (Spain). Parasitol Res 2009; 106(1): 183-188. PMid:19841943. http://dx.doi.org/10.1007/s00436-009-1647-y.
Mohsen A, Hossein H. Gastrointestinal parasites of stray cats in Kashan, Iran. Trop Biomed 2009; 26(1): 16-22. PMid:19696723.

Palmer CS, Thompson RC, Traub RJ, Rees R, Robertson ID. National study of the gastrointestinal parasites of dogs and cats in Australia. Vet Parasitol 2008; 151(2-4): 181-190. PMid:18055119. http://dx.doi. org/10.1016/j.vetpar.2007.10.015.

Ragozo AMA, Muradian V, Silva JCR, Caravieri R, Amajoner VR, Magnabosco C, et al. Ocorrência de parasitos gastrintestinais em fezes de gatos das cidades de São Paulo e Guarulhos. Braz J Vet Res Anim Sci 2002; 39(5): 244-246. http://dx.doi.org/10.1590/S1413-95962002000500005.

Ramos DGS, Scheremeta RGAC, Oliveira ACS, Sinkoc AL, Pacheco RC. Survey of helminth parasites of cats from the metropolitan area of Cuiabá, Mato Grosso, Brazil. Rev Bras Parasitol Vet 2013; 22(2): 201-206. PMid:23856737. http://dx.doi.org/10.1590/S1984-29612013000200040.

Ribeiro SR, Furst C. Parasitological stool sample exam by spontaneous sedimentation method using conical tubes: effectiveness, practice, and biosafety. Rev Soc Bras Med Trop 2012; 45(3): 399-401. PMid:22760145. http://dx.doi.org/10.1590/S0037-86822012000300024.

Riggio F, Mannella R, Ariti G, Perrucci S. Intestinal and lung parasites in owned dogs and cats from central Italy. Vet Parasitol 2013; 193(1-3): 78-84. PMid:23265188. http://dx.doi.org/10.1016/j.vetpar.2012.11.026.

Sheather AT. The detection of intestinal protozoa and monge parasites by a flotation technique. J Comp Pathol 1923; 36: 266-275. http://dx.doi. org/10.1016/S0368-1742(23)80052-2.

Smith KE, Zimmerman JJ, Patton S, Beran GW, Hill HT. The epidemiology of toxoplasmosis on Iowa swine farms with an emphasis on the roles of free living mammals. Vet Parasitol 1992; 42(3-4): 199-211. PMid:1496780. http://dx.doi.org/10.1016/0304-4017(92)90062-E.

Soulsby E. Helminths, arthropods and protozoa of domesticated animals. Philadelphia: Lea and Febiger; 1982. 809 p.

Stalliviere FM, Bellato V, Souza AP, Sartor AA, Moura AB, Rosa LD. Ectoparasites and intestinal helminths in Felis catus domesticus from Lages city, SC, Brazil and social-economical and cultural aspects of owners of family pets. Rev Bras Parasitol Vet 2009; 18(4): 26-31. PMid:20040205. http://dx.doi.org/10.4322/rbpv.01804005.

Taylor MA, Coop RL, Wall RL. Parasitologia veterinária. Rio de Janeiro: Guanabara Koogan; 2010. p. 299-388. 